\title{
Some Recent Archæological Discoveries in Lincoln
}

\section{the Rev. Precentor Venables}

To cite this article: the Rev. Precentor Venables (1891) Some Recent Archæological Discoveries in Lincoln, Archaeological Journal, 48:1, 186-189, DOI: 10.1080/00665983.1891.10852475

To link to this article: http://dx.doi.org/10.1080/00665983.1891.10852475

曲 Published online: 15 Jul 2014.

Submit your article to this journal 주

View related articles $\widetilde{ }$ 


\section{SOME RECENT ARCH EOLOGICAL DISCOVERIES IN LINCOLN. 1}

By the Rev, PRECENTOR VENABLES.

May I be permitted to lay before the Institute notes of some discoveries made during the last few months in and near Lincolı. None of them are of any great importance, but I think that they possess sufficient interest to warrant my communicating them to our monthly meeting. My doing so will ensure their being placed on record in the Journal, and prevent their being entirely forgotten.

I will begin with some discoveries of the Roman period. Some well preserved bits of the city wall were laid bare last June, in two places, one on the eastern half of the northern wall, the other on the northern portion of the eastern wall. The portions laid bare were of no considerable size, but the facing stones, which, in every other part of the wall now above ground, have been stripped off, were well preserved, thus giving the fragments interest and value.

The first fragment was discovered in the field to the north east of the well-known Roman gateway, the so-called "Newport Arch," in which stands the largest existing mass of the Roman wall, with the agger and fossa in an excellent state of preservation, offering an instructive example cf the mode of fortification adopted by the Romans in their provincial cities. Unhappily for the cause of history and archæology, the builder who has long looked covetously on this inviting piece of ground has commenced operations, and it is hardly likely that it will continue ofen long, and we may fear that Lincoln will soon lose one of its most characteristic historical features. ${ }^{2}$

For the erection of a wall running north to south, cutting off the east end of this field, a trench had to be clug, which cut across the line of the Roman wall, and laid bare its northern face at a point about $250 \mathrm{ft}$. to the east of the existing mass. The southern face was not exposed. The piece revealed was about $3 \mathrm{ft}$. in height, and about $4 \mathrm{ft}$. across. It was about 30 inches below the surface of the ground. Six courses of facing stones remained above the plain unmoulded set-off, each course being about five inches in height. Its masonry was of the same character with that of the square tower recently described in the Journal, vol. xlv, p. 485.

The other portion was in the nothern part of the east face, to the south of the eastern gate, almost midway between that and the south east angle of the city. Its position was immediately to the north of the vestibule of the Chapter House, just outside the east cloister wall. It was discovered when forming a heating chamber for the Chapter House and Library, beneath the staircase to the latter. The masonry was of the same characler as that already described. Additioual interest attaches to this fragment from its having a bold well-dereloped base-moulding, instead of the plain

1 Read at the Monthly Meeting of the Institute, December 4th, 1890.

2 Since this paper was written the most important portion of this field, including the large fragment of wall referred to above has been purchased by
Alfred Shuttleworth, Esq., to secure the preservation of these interesting relics of Roman Lincoln. The Archæological world cannot fail to feel very grateful tw this gentleman for his well directed liberality. 
sloping set-off common to the ozher parts of the wall. Of this I send a full-sized section taken by Mr. J. J. Smith, the clerk of the works to the Cathedral. On the same paper is a plan shewing the position of this fragment. It will be noticed that traces of a second wall were discovered parallel to the first. It was impossible to investigate this without disturbing the foundations of existing buildings, and its relation to the general system of the walls cannot therefore be determined.

To pass outside the city walls, traces of a Roman villa were discovered during the month of October, in the Greetwell Fields, about a mile from the east of the city, where the subjacent beds of ironstone are being very extensively worked. The situation is on the brow of the steep slope, which here descends to the valley of the Witham, with a full southerly exposure; seven or eight years ago traces of a bath or cistern were discovered a few yards to the south of this spot. I was unfortunately absent from Lincoln at the time of this former discovery, but it was carefully recorded by Dr. O'Neill of Lincoln, whose account is printed in the forty-first volume of the Joumal (1884), p. 32 . What has been recently laid bare, about $3 \mathrm{ft}$. bolow the surface, consists of portiuns of a plain tesselated pavement, formed of long strips of red tesseræ of brick 5 in. wide, alternately with strips of whitc tesseræ of stone $9 \mathrm{in}$. wide, running north and south and stopped at the north end by a row of square tiles, impressed with diagonal lines. The portion laid bare was about $7 \mathrm{yds}$. long by $19 \mathrm{yds}$. wide. As the works proceed more will doubtless be discovered, of which careful note will be taken. About $3 \mathrm{ft}$. lower than the tesselated floor to the west was a cement floor, from which rude steps led up to the higher level. The only object of antiquity discovered, as far as I could learn, was a small brass coin of Gallienus, bearing on the obverse a stellated bust of the Emperor, and on the reverse a Capricorn. This I send for inspection. We cannot doubt that we have here the remains of the country house of one of the chief inhabitants of the Roman city, perhaps an officer high in command, desiring like Hurace's Mæcenas, to avoid " fumum et opes strepitumque Lindi," retired to the green sunny pastures stretching to the east of its walls, a little to the south of the road to Bannovallum, the modrn Horncastle.

Another memorial of the Roman occupation I send in the shape of a box of teeth, specimens of a considerable quantity recently dug up in a garden within the walls of the small stationary camp of Caistor, to the north of Lincoln. A similar find of jaw bones was made in connection with the Roman portico, discovered at Lincoln a few years buck, and described in this Jounnal. These were submitted to the late Professor Rolleston of Oxford, who pronounced them to be those of young animals of the "Bos Longifrons." It is well known that in the want of winter food for their stock the Romans were in the habit of killing off their young animals on the setting in of cold weather, and salting down the bodies and limbs for domestic consumption. The heads would be eaten fresh, probably forming the staple of many a savoury mess of sheepshead broth, the jaw bones and teeth going to the kitchen-midden, which, as the recognized depository of all unclean and superfluous culinary waste, now yields such rich stores of lnowledge as to the domestic life of men of bygone generations. Wishing to have a professional opinion on these teeth I submitted them to Dr, E, Mansel Sympson of Lincoln, who wrote 
as follows:- "I have no doubt about the teeth belonging all save one to the ox tribe; but to make sure I compared them with those at Allis's, pronounced by Prof. Rolleston to be those of the Bos Longifrons, and found them agree. I append a few brief notes.

"One tooth undoubtedly a horse's molar.

"One molar tooth on part of the jaw from an old Bos longifrons.

"One smaller from Bos longifrons.

"One threefanged tooth from a young Bos.

"I am not quite clear what the two smaller teeth are, one looks as though it had never been used at all, the other looks very like a sheep's tooth."

Descending from Roman to mediæval times, I have the pleasure of laying before the meeting some relics discovered during the month of October on the site of St. Catherine's Gilbertine Priory, in the suburbs of Lincoln, in digging the foundations of a new house. Several stone coffins and skeletons were turned up, some of these being in the coffins and others in layers three or four deep. One skeleton the builder alleged"credat Judæus"-was found "doubled up and built into a wall" There were several incised monumental slabs, but much broken and defaced. Mr. W. Scorer, Architect, of Lincoln took a rubbing of the most perfect of the slabs, which had remains of a marginal inscription, but no more was legible than the first letters of the date Moccc.... A considerable number of architectural fragments were also found, chiefly moulded arch stones, and groining ribs of the Early English period, of which Mr. Scorer took outlines, also a very large and bold plinth or base mould of early Transitional character, probably belonging to the time of the foundation of the Priory by Bishop Robert of Chesney 1148.

The following objects have been lent to me by the builder, Mr. Copley, for the purpose of exhibiting to the Institute.

(1) A small ivory or bone seal, of a pointed oval, or curved lozenge shape, $1 \frac{1}{4}$ in. by $1 \mathrm{in}$.. with a silver link at the top for attaching to a chain. It bears a bird with outspreadings and extended claws. Round the margin is the legend "Tecta lege, Lecta tege." "Read what is hidden, and hide it when read."

(2) A leaden "Bull" of Pope Innucent VI., A.D. 1352-1362. It is of the normal type, the obverse bearing the heads of St. Peter (sinister) with short hair and closely cropped beard, and St. Paul (dexter) with bald head and long pointed beard. The names have been erased with the exception of (E.) above St. Peter. Each head is set in an oval; between them in the lower part of the interspace is a small cross. The reverse bears - INNOCETIVS $\overline{\mathrm{PP}} \mathrm{VI}$.

(3) A double socket of brass on which I desire the opinion of the meeting. It appears to have formed part of a padlock.

(4) A shield, set in a quatrefoil, from a monumental brass bearing two crosses in chief, a crescent in base, with an estoile above. Can any member identify the charge?

I have also sent for inspection three Bronze Celts dug up in a field known as the "Church Piece," a short distance to the west of the church of Fiskerton, five miles east of Lincoln, in 1890. One is marked with small ridges three in front and one on each side, which are thought by some to mark an early date. I am indebted for these to the Rev. T. H. Vines, Vicar of Fiskerton. 
A few weeks since in digging the foundations of a new house on the site of the Gilbertine Priory of St Catherine, without the Bargate, the former south entrance into Lincoln, several objects of antiquity were discovered of which it is hoped to lay a fuller account before the next meeting of the Institute. A number of stone coffins containing skeletons were laid bare together with several incised monumental slabs broken and defaced. One slab only was sufficiently perfect to allow a rubbing to be taken, but the letters were to much decayed to be deciphered, with the exception of a fragment of the date uCOCC . . . . . Some architectural remains were dug up in the shape of carved stones, such as arch molding, vaulting ribs, and the like, of the Early English period; also one piece of a very bold base molding or plinth of Norman character, evidently belonging to the first buildings of the Priory, which was founded in 1139. Several smaller objects were discovered, especially the wafer seal of a Papal bull bearing the heads of St. Peter and St. Paul on one side, and the name of Pope Innocent VI, 1352-1362, on the other; a small ornamental oval bune tablet, with a ring to suspend it round the neck; a brass quatrefoil enclosing a shield bearing two crosses in chief and a crescent in base, above which is a mullet, once belonging to a monumental brass; and other objects, of which want of time prevents my writing more particularly now. 